AGRICULTURE AND BIOLOGY JOURNAL OF NORTH AMERICA

ISSN Print: 2151-7517, ISSN Online: 2151-7525, doi:10.5251/abjna.2011.2.4.661.664

(C) 2011, ScienceHu $\beta$, http://www.scihub.org/ABJNA

\title{
Volume and value of ornamental fishes in the Nigerian export trade
}

\author{
*Ukaonu, S.U., Mbawuike, B. C., Oluwajoba, E.O., Williams, A.B. \\ Ajuonu, N. Omogoriola H.O., Olakolu, F.C. Adegbile, O.M. and Myade, E.F. \\ Marine Biology Section, Nigerian Institute for Oceanography and Marine Research \\ P.M.B.12729 Victoria Island Lagos, staklins@yahoo.com
}

\begin{abstract}
There are about 70 commonly exported species of ornamental fish (fresh \& marine water species) in the Nigerian export trade. In 2006 the association of live fish exporters (NAOFFEN) was made up of 60 members but only 40 companies had the export permit in 2007 . The total volume of ornamental fish exported in 2006 was 1,292,259 at the value of $\$ 711804$.37 while in 2007 the value dropped to $1,132,286$ at the value of $\$ 662,611.35$.
\end{abstract}

Keyword: volume, value, ornamental fish, export trade

\section{INTRODUCTION}

Ornamental fish is often used as a generic term to describe aquatic animals kept in the aquarium, including fish, invertebrates such as corals, crustaceans (e.g. crab, hermit crab, and shrimps), mollusk (e.g. snail, clams, scallops) and also live rock. Aquarium keeping is amongst the most popular of hobbies with millions of enthusiasts' world wide. Around 2000 species and millions of specimens are traded annually in the ornamental fish trade (Livengood and Chapman 2009).

Ornamental fish trades have been on the increase during the last decade. The global trade in ornamental fish and associated aquarium accessories is in excess of U.S. $\$ 7 \times 10^{9}$ each year (Andrew 2006). Together all countries of the European union are the largest market for ornamental fish; however United states (US) is the single largest importer of ornamental fish in the world (FAO 1996-2005). Although the exact figure on the value and quantity of ornamental fish industry do not exist, the value of ornamental fish and invertebrates imported into different countries world wide is approximately \$278 million US dollars (FAO 19962005).

Globally, the ornamental fish trade and its associated industries have important economic status and a major source of overseas income in Africa, South America and South East Asia (Andrew 1991). Ornamental fish export trade has been carried out in
Nigeria for over forty years Areola (2004). It was started by some Americans who invested heavily into the identification and location of these species per water body and still send in requests till date. The export trade is growing in Nigeria, earning over $\$ 1.5 \mathrm{~m}$ with about 100 identified species (Koroye, 2010; Areola, 2004). These ornamental fish species are mainly removed from the wild by fisher folk who in turn supply to the exporters. Meanwhile the sustainability of the stock is not guaranteed. Little or no documented data are available on the volume and value of ornamental fish traded in Nigeria. This report will provide baseline data of the volume and value of ornamental fish exported out of the country. Such documentation is needed to provide background information for future management decision for sustainability of the resources and on the other hand ensure that Nigeria retains its share of this important and growing market.

\section{MATERIALS AND METHOD}

The data for this report were derived from the Nigerian Agricultural Quarantine Services NAHCO COMMAND. These data are collected by quarantine services officer at the Nigerian Aviation handling company (Export shed) of the Muritala Muhammed Int'l Airport II FAAN Hqtrs, Ikeja, Lagos. They issue out data sheet to licensed ornamental fish exporters. This data sheet record information on the species or fish type, volume or quantity parked in each box, country of initial sale and their value in USD. The exporter formed an association called National Association of Ornamental Fish Farmers and 
Exporters (NAOFFE). The exporters buy fish either from wholesalers or directly from collectors. In some cases the exporter may employ his own collectors or breed some species of ornamental fish in his farm. He keeps the fish in quarantine for a period of few days to a few months depending on the health of the fish, to detect potential diseases and acclimatize the fish. The consignment for export must be checked by the agricultural quarantine services to obtain a phytosanitary or health certificate before issuing out data sheet to the exporter. Thereafter the consignment will be declared to the customs for shipment. This data, which includes both fresh and marine water life collected live in Nigeria and retained for commercial and export purposes, is summarized in the following section.

\section{RESULTS AND DISCUSSION}

In 2006 the association of live fish exporter (NAOFFEN) was made up of 60 members but only 40 companies had the export permit in 2007. Between 2009 and 2010 about 29-33 companies got the export permit. The ornamental fish landings in Nigeria include species of both fresh and marine water fishes collected live and intended for aquarium industry (i.e. commercial purposes). The total volume exported in 2006 was $1,292,259$ which decreased to $1,132,286$ in 2007 about $12 \%$ decreases in quantity exported.

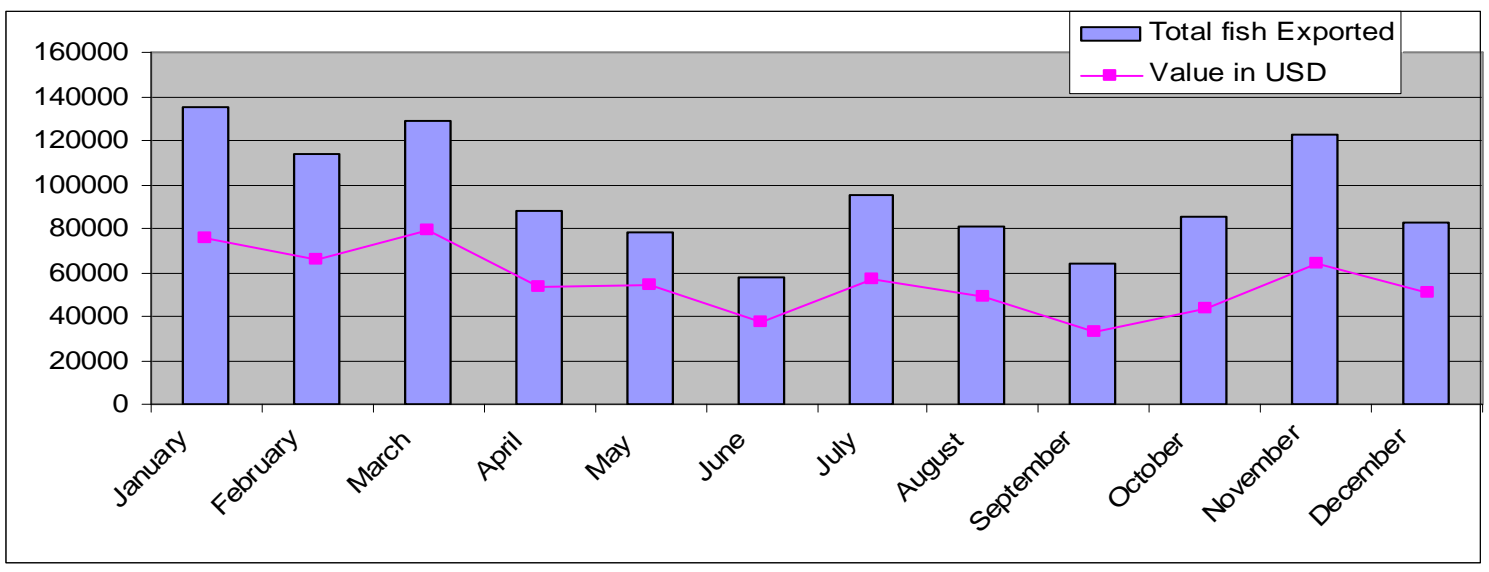

Fig 1. 2007 Total fish exported according to months and their value in USD

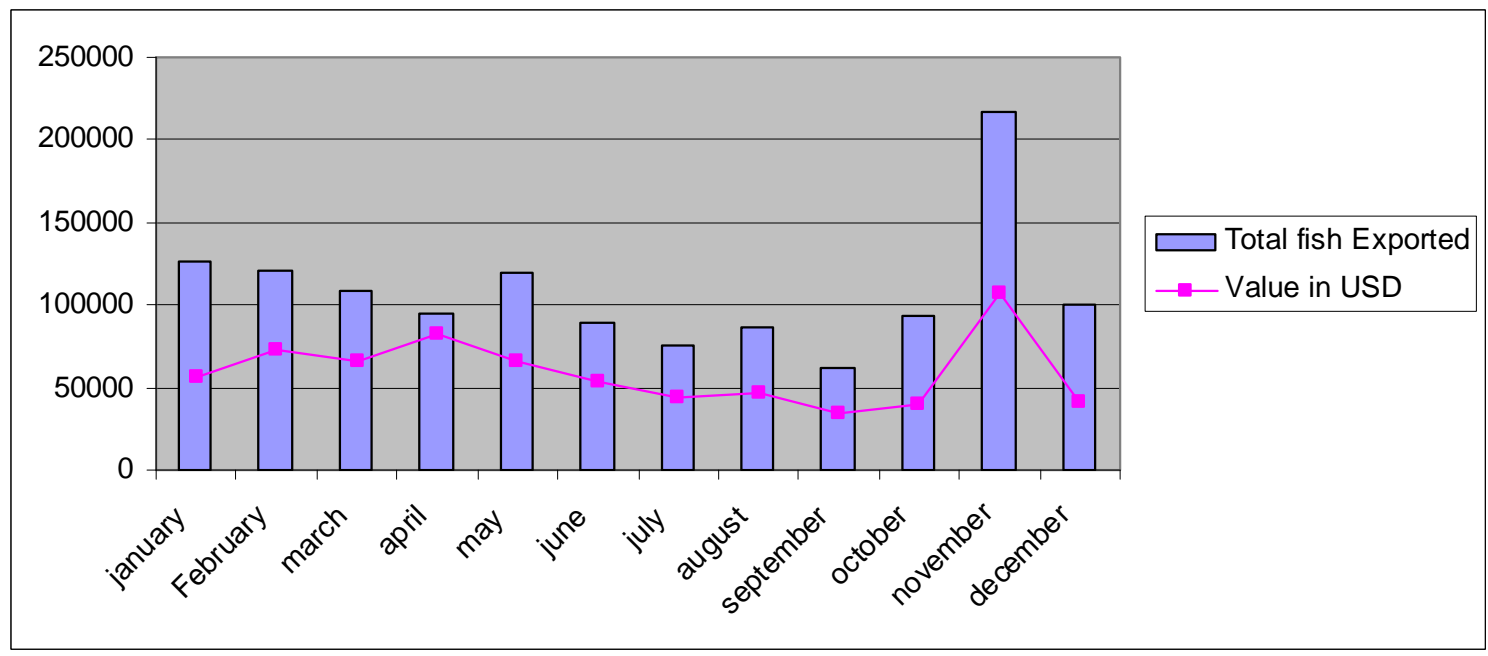

Fig 2. 2006 Total fish exported according to months and value in USD. 
This decrease in the trend of the trade was also found in the value of the ornamental fish export as the case may be. The total value of the exported live fish decreased from $\$ 711,804.37$ in 2006 to $\$ 662,611.35$ in 2007 (Figure 1 \&2). The decline in volume and value since 2007 can be accounted for by the global recession problems and also the introduction of the internet. The consumers are usually kids and these days they find sitting in front of their computers surfing the nets more interesting than looking at or feeding aquarium fish. These have caused decline in demand of aquarium fish. About 100 species of ornamental fish have been identified in Nigeria and commonly exported ones are listed in table 1 according to their economic importance and unit price in USD.

\section{Table 1: Quantity of fish packaged in a box and the unit price in USD}

\begin{tabular}{|c|c|c|c|c|}
\hline S/No & Common name & Scientific name & Qty per box & Unit price US \$ \\
\hline 1 & Long nose & Gnathonemus petersii & 100 & 0.8 \\
\hline 2 & Short nose & Marcusenius angolensis & 200 & 0.5 \\
\hline 3 & Round nose & Pollymyrus nigipinnis & 200 & 0.3 \\
\hline 4 & Dolphin fish & Mormyrus longirostius & 40 & 1.5 \\
\hline 5 & Whales shortnose & Brienomyrus brachyistius & 200 & 0.5 \\
\hline 6 & Baby aba & Gymnarchus niloticus & 400 & 1 \\
\hline 7 & Butterfly & Pantodon bucholzi & 200 & 0.35 \\
\hline 8 & Spiny eel & Afromastacenbelus loennbergi & 700 & 0.5 \\
\hline 9 & Reed & Erpetiochthys calabaricus & 200 & 0.4 \\
\hline 10 & Snake head & Channa obscura & 600 & 0.4 \\
\hline 11 & Polypterus & Polypterus conginus & 200 & 0.8 \\
\hline 12 & Polypterus & Polypterus lapradi & 40 & 3 \\
\hline 13 & Polypterus & Polypterus endlicheri & 20 & 10 \\
\hline 14 & Arowana & Heterotis niloticus & 150 & 1 \\
\hline 15 & Mudskipper & Petriopthalmus barbatum & 150 & 1 \\
\hline 16 & Africa lungfish & Protopterus annectens & 50 & 0.3 \\
\hline 17 & Moon fish & Citharinus citharus & 50 & 3 \\
\hline 18 & Labeo & Labeo senegalensis & 50 & 2 \\
\hline 19 & Puffer & Tetradon fahaka & 200 & 0.8 \\
\hline 20 & Ocellifer & Synodontis robertis & 200 & 0.8 \\
\hline 21 & Puffer ( big size) & Tetradon fahaka & 200 & 1 \\
\hline 22 & Lusoso & Distichodus maculates & 60 & 3 \\
\hline 23 & Mono & Monodactylus sebae & 100 & 1 \\
\hline 24 & Neolebias & Neolebias powelli & 1300 & 0.6 \\
\hline 25 & Bush fish & Ctenopoma kingslayae & 200 & 0.5 \\
\hline 26 & Lates & Lates niloticus & 23 & 15 \\
\hline 27 & Barboides & Barboides graccilis & 1500 & 0.4 \\
\hline 28 & One line tetra & Neolebias unifasciatus & 600 & 0.3 \\
\hline 29 & Leaf fish & Monocirhus pollyacanthus & 300 & 0.5 \\
\hline 30 & Needle fish & Microphis aculeatus & 200 & 1 \\
\hline 31 & Sylvaticus & Barbus sylvaticus & 600 & 0.8 \\
\hline 32 & Stingray & Dasyatis margarita & 2 & 150 \\
\hline 33 & Kribensis & Pelvicachromis pulcher & 200 & 1 \\
\hline 34 & Jewel & Hemichromics spp & 200 & 0.5 \\
\hline 35 & Zebra & Tilapia marie & 200 & 0.4 \\
\hline 36 & Blue fish & Aplocheilichthys myersi & 800 & 0.3 \\
\hline 37 & Aphyosemion & Aphyosemion gardneri & 800 & 0.3 \\
\hline 38 & Procatopus & Procatopus aberranus & 600 & 0.6 \\
\hline 39 & Panchax (blue) & Aplocheilichthys & 1000 & 0.3 \\
\hline 40 & Big aphyosemion & Aphyosemion sjoestedti & 200 & 1 \\
\hline 41 & Diamond fish & Denticeps clupeoides & 200 & 1 \\
\hline 42 & Normanni & Aplocheilus luxopthalmus & 1000 & 0.3 \\
\hline 43 & Upside down cat & Synodontis nigrita & 400 & 0.3 \\
\hline
\end{tabular}


Agric. Biol. J. N. Am., 2011, 2(4): 661-664

\begin{tabular}{|l|l|l|l|l|}
\hline 44 & Debawei & Eutorpiellus debauwi & 300 & 0.3 \\
\hline 45 & Network & Synodontis eupterus & 200 & 0.8 \\
\hline 46 & Occellifer & Synodontis robertis & 200 & 0.8 \\
\hline 47 & Giraffe nose & Auchenoglanis occidentalis & 50 & 2 \\
\hline 48 & Aluminium cat & Gephyroglanis longipinnis & 150 & 1 \\
\hline 49 & Glass cat & Parailia peellucida & 400 & 0.4 \\
\hline 50 & Dwarf cat & Microsynodontis batesii & 1500 & 0.5 \\
\hline 51 & Bagrus & Bagrus bayad & 50 & 3 \\
\hline 52 & Red-tail cat & Synodontis clarias & 100 & 2 \\
\hline 53 & Striped cat & Clarotes laticeps & 50 & 2 \\
\hline 54 & Spotted cat & Synodontis spp & 300 & 0.5 \\
\hline 55 & Apple cat & Synodontis eburnensis & 200 & 0.5 \\
\hline 56 & Whip tail & Belonoglanis tenuis & 300 & 1 \\
\hline 57 & Eel cat & Chanallabes apus & 300 & 0.5 \\
\hline 58 & Electric cat & Malapterurus electricus & 400 & 0.6 \\
\hline 59 & Medium electric cat & Malapterurus electricus & 100 & 1 \\
\hline 60 & Membranaceus & Hemisynodontis membraneceus & 100 & 2 \\
\hline 61 & African pike & Hepsetus odoe & 50 & 2 \\
\hline 62 & Red eye & Arnoldichthys spilopterus & 300 & 0.5 \\
\hline 63 & Red tail alestes & Micralestes stormsi & 150 & 1 \\
\hline 64 & Congo tetra & Phemacogrammus interruptus & 300 & 0.4 \\
\hline 65 & Alestes & Brycinus longipinnis & 300 & 0.3 \\
\hline 66 & Red tail tiger & Hydrocynus goliathus & 23 & 15 \\
\hline 67 & megalops & Megalops atlanticus & 20 & 20 \\
\hline 68 & Blue alestes & Alestopetersius smykalai & 200 & 1 \\
\hline 69 & Knife fish & Xenomystus nigrii & 200 & 0.5 \\
\hline 70 & Marble knife & Papyrocranus afer & 70 & 1 \\
\hline & & &
\end{tabular}

\section{REFERENCES}

Adams, C.M., S.L. Larkin and D. J. Lee (2001): Volume and Value of marine ornamentals collected in Florida, 1990-98. Aquarium Science and Conservation $3: 25-36$

Areola, F.O. (2004): Export potential of ornamental live fishes in Nigeria. FISON conference Proceedings 2004, P589.

Andrews C. (1992): The ornamental fish trade and conservation. In infofish international number 2/92 March/April

Bertley, D. (2000): Responsible ornamental fisheries FAO Aquaculture Newsletter No. 24.AO. Rome.
Oliver, K (2001): ornamental fish trade- overview. In infofish international 3/2001. May/june

Aquaculture News (2001): In infofish international 3/2001. May/June.

Livengood, E.J. and F.A. Chapman (2009): The ornamental fish trade: An introduction with perspective for responsible aquarium cooperative extension service, institute of food and agricultural science, university of Florida Gainesville FL 32611.

Koroye, E. (2010): Exporting Ornamental Fish is Big Business. African Aquaculture \& Fisheries Digest, vol. 3, No8: 11, 2010. 